\title{
POTENSI DAN RIAP DIAMETER JENIS Aquilaria malaccensis LAMK DI HUTAN ALAM PRODUKSI LABANAN, KABUPATEN BERAU, KALIMANTAN TIMUR
}

\section{(Potency and Diameter Increment of Aquilaria malaccensis LAMK at Labanan Natural Production Forest, Berau District, East Kalimantan)*)}

\author{
Oleh/By: \\ Abdurachman, Amiril Saridan, dan/and Ida Lanniari \\ Balai Besar Penelitian Dipterokarpa \\ Jl. A. Wahab Syahrani, Sempaja - Samarinda Telp. (0541) 206364 Fax. (0541) 742298 \\ e-mail : bpk-smd@samarinda.org Website : www.bp2k.go.id \\ *) Diterima : 17 April 2008; Disetujui : 10 Maret 2009 \\ klasifikasi \\ ABSTRACT
}

Aquilaria malaccensis LAMK is one of the most important tree species which can produce agarwood or gaharu as non timber forest product in East Kalimantan. Agarwood has a high economical value. The objective of this research is was to get information on potency, distribution, and diameter increment of the trees. Such information provides an important input for genetic conservation purpose as well as for silviculture development. This research was conducted at Silviculture Technique for Regeneration of Logged Over Area in East Kalimantan (STREK) plots at Labanan natural production forest with a total area of 48 ha. The areas were divided into12 plots, where each plot has a size of 4 ha or $200 \mathrm{~m} \times 200 \mathrm{~m}$. The result showed that the total trees on each plot was between 1 to 5 trees, which meant that only 1 tree could be found in every two ha. The maximum diameter of the tree was $44.7 \mathrm{~cm}$ while the minimum diameter was above $10.0 \mathrm{~cm}$. The average of diameter increment was $0.40 \mathrm{~cm}( \pm 0.402 \mathrm{~cm})$ per year. Meanwhile, the maximum growth was $0.64 \mathrm{~cm}$ per year for diameter class $>40 \mathrm{~cm}$.

Keywords: Agarwood, non timber forest product, silviculture, maximum growth

\begin{abstract}
ABSTRAK
Aquilaria malaccensis LAMK adalah salah satu jenis tanaman penting yang dapat memproduksi gaharu sebagai hasil hutan bukan kayu di Kalimantan Timur. Gaharu memilki nilai ekonomi tinggi. Tujuan penelitian ini adalah untuk memperoleh informasi potensi, distribusi, dan riap diameter pohon penghasil gaharu. Diharapkan informasi ini dapat dijadikan dasar untuk konservasi genetik dalam pengembangan silvikultur. Penelitian ini dilaksanakan pada plot STREK (Silviculture Technique for Regeneration of Logged Over Area in East Kalimantan) di hutan alam produksi Labanan dengan total kawasan 48 ha. Telah dibuat 12 plot di mana setiap plot berukuran empat ha atau $200 \mathrm{~m} \mathrm{x} 200 \mathrm{~m}$. Hasil penelitian menunjukkan bahwa jumlah pohon pada setiap plot berjumlah 1-5 pohon, ini berarti hanya ada satu pohon dalam luasan dua ha. Diameter terbesar adalah $44,7 \mathrm{~cm}$ dan terkecil $10 \mathrm{~cm}$ Rata-rata riap diameter adalah $0,40 \mathrm{~cm}$ per tahun $( \pm$ $0,402 \mathrm{~cm}$ ). Sementara itu, riap tertinggi adalah $0,64 \mathrm{~cm}$ per tahun untuk kelas diameter $>40 \mathrm{~cm}$.
\end{abstract}

Kata kunci: Gaharu, hasil hutan bukan kayu, silvikultur, pertumbuhan maksimum

\section{PENDAHULUAN}

Hutan tropis dataran rendah yang terdapat di Indonesia, khususnya di Kalimantan mempunyai keanekaragaman jenis yang sangat tinggi, baik flora maupun fauna. Kekayaan sumberdaya hutan tersebut telah dapat memberikan penghasilan yang sangat besar, oleh karena itu maka pemanfaatannya secara berkesinambungan harus dapat dijaga. Agar kekayaan ter- sebut dapat dimanfaatkan secara optimal, maka diperlukan penelitian tegakan hutan untuk mengetahui secara pasti potensi tegakan serta persebaran suatu jenis tertentu dalam suatu kawasan hutan.

Peranan sumberdaya hutan alam dalam kehidupan masyarakat modern makin meningkat menyangkut jenis, bentuk, ukuran maupun keragamannya. Hal ini didorong oleh makin majunya ilmu pengetahuan dan teknologi yang dikuasai 
manusia dalam rangka pemanfaatan keseimbangan fungsi sumberdaya hutan (Junus et al.,1985). Selanjutnya dikatakan pula bahwa dalam memanfaatkan sumberdaya hutan ini maka kita harus berpegang dan bertolak dari informasi tentang hutan tersebut, yaitu tentang besarnya riap dan potensi hutan yang ada disertai penggunaan dan penerapan teknik kehutanan yang benar.

Salah satu potensi hutan yang berupa hasil hutan bukan kayu adalah Aquilaria malaccensis LAMK yang merupakan salah satu jenis penghasil gaharu. Penggunaan gaharu pada mulanya hanya sebagai pengharum tubuh, ruangan, dan bahan baku pembuat dupa, tetapi dengan adanya kemajuan ilmu pengetahuan dan teknologi maka penggunaannya juga mengalami perkembangan antara lain sebagai bahan baku industri parfum dan bahan pengikat wewangian. Selain itu, juga secara tradisional gaharu diyakini dapat menyembuhkan berbagai macam penyakit. Penebangan gaharu ini telah lama dilakukan oleh masyarakat dan terus meningkat karena adanya permintaan pasar luar negeri yang tinggi. Namun sangat disayangkan kebanyakan dari pencari gaharu tersebut kurang memiliki pengetahuan tentang konservasi dan pelestarian sumberdaya alam yang memadai serta pengetahuan mengenai ciri-ciri pohon yang mengandung gaharu. Pemungutan gaharu oleh masyarakat dalam kawasan hutan dilakukan dengan cara yang sangat tradisional yaitu dengan menebang pohon yang diduga mengandung gaharu dan mencincangnya dengan menggunakan parang atau kapak. Praktek semacam ini dapat menyebabkan keberadaan jenis tersebut dalam kawasan hutan semakin berkurang.

Untuk menjaga agar jenis pohon penghasil gaharu tersebut terhindar dari kepunahan, maka pada pertemuan CITES (The Convention on International Trade of Endangered Species of Wild Flora and Fauna), ke-IX tahun 1994 di Florida, Amerika Serikat memasukkan A. malac- censis ke dalam daftar tumbuhan langka di kelompok Appendix II CITES.

Sehubungan dengan hal tersebut, tulisan ini dimaksudkan untuk memberikan informasi mengenai potensi dan persebaran serta riap pohon $A$. malaccensis di hutan alam Labanan, informasi ini dapat digunakan sebagai bahan masukan dalam penyusunan kebijakan lebih lanjut di bidang konservasi dan budidaya jenis pohon tersebut.

\section{METODOLOGI PENELITIAN}

\section{A. Lokasi dan Waktu}

Lokasi penelitian terletak di kawasan hutan Labanan, merupakan plot penelitian permanen kerjasama antara Balai Penelitian Kehutanan Samarinda, PT. Inhutani I Berau dan Berau Forest management Project (BFMP) di mana plot ini sebelumnya merupakan kegiatan Silvicultural Tecniques for the Regeneration of Logged Over Forest in East Kalimantan (STREK) Project yang berada di Berau Kalimantan Timur. Secara geografis wilayah tersebut terletak pada posisi $1^{0} 45^{\prime}$ $2^{0} 10^{\prime}$ LU dan $116^{0} 57^{\prime}-117^{0} 27^{\prime}$ BT. Berdasarkan data iklim Stasiun Bandara Kalimarau Tanjung Redeb Kabupaten Berau, rata-rata curah hujan tahunan 2.404 $\mathrm{mm}$, bulan kering terjadi pada bulan Agustus dan September, sedangkan bulan basah terjadi pada bulan Desember dan Januari. Tipe iklim menurut Schmidt dan Ferguson (1951) lokasi penelitian memiliki nilai $\mathrm{Q}=16,17 \%$ tergolong tipe iklim $\mathrm{B}(\mathrm{Q}=14,3-33,3 \%)$, sementara di bagian selatan memiliki nilai $\mathrm{Q}=4,20 \%$ termasuk tipe iklim A dengan curah hujan ratarata 2.500-3.000 $\mathrm{mm}$ per tahun. Suhu udara maksimum $35^{\circ} \mathrm{C}$ terjadi pada bulan September dan November dan terendah $33^{0} \mathrm{C}$ pada bulan Januari. Suhu udara minimum tertinggi $22^{\circ} \mathrm{C}$ terjadi pada bulan Mei dan Juni dan minimum terendah $21^{0} \mathrm{C}$ terjadi pada bulan Februari dan Agustus. Jenis tanah didominasi oleh 
Podsolik Haplik (Typic Paleudults) dan Podsolik cromik (Typic Hapluduts). Tanah-tanah tersebut memiliki tekstur lempung, lempung liat berpasir hingga lempung berliat dan liat berwarna coklat kekuning-kuningan dengan struktur gumpal tak bersudut hingga bersudut. Drainase sedang hingga baik dan kedalaman efektif adalah $>100 \mathrm{~cm}$. Topografi daerah ini memiliki tingkat kelerengan ringan atau datar. Kondisi tersebut meliputi 36\% dari luas kawasan, sedangkan luas kawasan lainnya dicirikan dengan kondisi kelerengan curam yang meliputi 25\% dari luas kawasan. Kelerengan lebih dari $40 \%$ meliputi 5,58\% dari luas wilayah pengelolaan hutan Labanan yang dikategorikan sangat curam (Anonim, 1999).

Menurut Sist dan Saridan (1998), pada kawasan ini terdapat sebanyak 76 Dipterocarpaceae. Penelitian dilaksanakan pada bulan Juni-Juli 2003.

\section{B. Pengumpulan Data Lapangan}

Data di lapangan diperoleh dari pengukuran pohon penghasil gaharu di plot penelitian STREK yang telah dibuat secara permanen sebanyak 12 buah masingmasing seluas empat hektar (200 m x 200 $\mathrm{m})$. Plot berbentuk bujur sangkar yang dibagi ke dalam empat kuadran dengan luas masing-masing satu ha. Bagan plot penelitian seperti tertera pada Gambar 1.

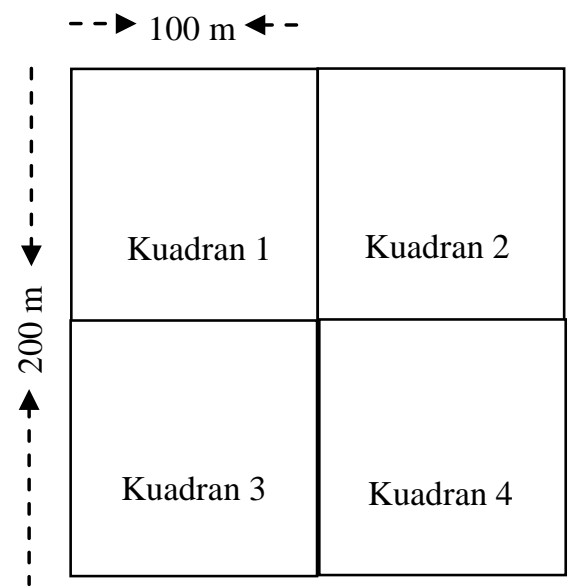

Gambar (Figure) 1. Skema Petak Ukur Permanen (PUP) seluas empat hektar di plot STREK, Labanan Kalimanatn Timur (Permanent sample plot four ha wide at STREK plots, Labanan East Kalimantan)
Pencatatan data terhadap pohon penghasil gaharu yang terdapat pada setiap kuadran dalam plot dilakukan secara sensus. Pengukuran dilakukan pada pohon yang mempunyai diameter $10 \mathrm{~cm}$ dan ke atas dengan menggunakan alat ukur phiband. Pengukuran juga dilakukan untuk mengetahui kerapatan dan riap pohon penghasil gaharu yang terdapat dalam lokasi penelitian.

\section{Analisis Data}

Menghitung diameter (d), luas bidang dasar (g), dan riap diameter (Rd):

1. Diameter pohon diperoleh dari konversi keliling sebagai berikut:

$\mathrm{D}=\mathrm{K} / \pi$

di mana:

$\mathrm{D}=$ diameter pohon $(\mathrm{cm})$

$\mathrm{K}=$ keliling pohon $(\mathrm{cm})$

$\pi=$ konstanta $p h i=3,1415$

2. Bidang dasar diperoleh dari persamaan luas lingkaran sebagai berikut:

$\mathrm{G}=1 / 4 \cdot \pi \cdot \mathrm{d}^{2}$

di mana:

$\mathrm{G}=$ bidang dasar pohon $\left(\mathrm{cm}^{2}\right)$

$\mathrm{d}=$ diameter pohon

$\pi=$ konstanta $p h i=3,1415$

3. Riap diameter pohon diperoleh dari rumus berikut:

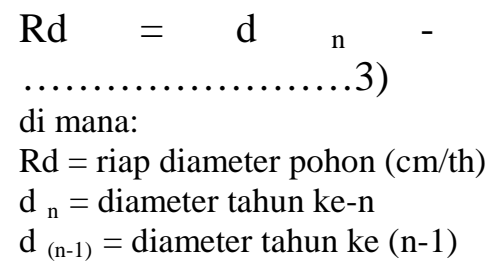

Data dari hasil pengukuran selanjutnya diolah dalam bentuk perhitungan berdasarkan Snedecor \& Cochran (1956) sebagai berikut:

1. Nilai rata-rata $(\mathrm{x})$

$$
\bar{X}=\sum X_{i} / n
$$

2. Nilai simpangan baku (sd) dan ragam $\left(S^{2}\right)$ 


$$
\begin{aligned}
& S_{d}=\sqrt{\frac{\sum x^{2}-\left(\sum x\right)^{2} / n}{n-1}} \\
& S^{2}=\frac{\sum x^{2}-\left(\sum x\right)^{2} / n}{n-1} \ldots
\end{aligned}
$$

3. Nilai galat baku (Se)

$$
S_{e}=\sqrt{\frac{\sum x^{2}-\left(\sum x\right)^{2} / n}{n(n-1)}}
$$

di mana:

$\mathrm{x}_{\mathrm{i}}=$ nilai pengamatan individu ke-i

$\mathrm{n}$ = ukuran sampel pangamatan

\section{HASIL DAN PEMBAHASAN}

\section{A. Potensi}

\section{Sebaran dan Jumlah Batang}

Dari hasil data pengukuran dan pengamatan yang telah dilakukan di plot penelitian sebanyak 12 plot atau 48 ha, diperoleh gambaran seperti tertera pada Tabel 1 .

Dari Tabel 1 dapat diketahui bahwa di lokasi penelitian seluas 48 ha ditemukan sebanyak 29 pohon dengan sebaran kelas diameter antara $10 \mathrm{~cm}$ sampai $40 \mathrm{~cm}$, dengan rata-rata 0,61 pohon/ha. Diameter maksimum yang ditemui pada plot mencapai $44,7 \mathrm{~cm}$.

Kehadiran pohon penghasil gaharu menyebar hampir merata pada semua plot, kecuali pada plot empat (tidak ditemukan). Hal ini disebabkan oleh faktor habitat, di mana jenis ini tidak mampu hi- dup pada kondisi tempat tumbuh yang tidak sesuai. Kondisi seperti ini dijelaskan oleh Marsono (1972) dalam Saridan (1984) bahwa kehadiran suatu jenis dalam suatu tempat atau tapak ditentukan oleh beberapa faktor yang dapat diuraikan sebagai berikut:

a. Habitat akan mengadakan seleksi terhadap jenis-jenis tertentu yang mampu hidup menyesuaikan diri dengan keadaan lingkungan setempat.

b. Waktu dengan sendirinya diperlukan untuk mengatasi hal ini, dengan berjalannya waktu vegetasi akan berkembang ke keadaan yang stabil.

c. Komposisi vegetasi ditentukan juga oleh adanya kesempatan untuk mengembangkan diri.

d. Kehadiran satu jenis dapat ditentukan pula oleh vegetasi yang ada di sekitarnya.

Dilihat dari pola hidupnya, ternyata jenis pohon penghasil gaharu dapat dikatakan tumbuh secara soliter dan sangat jarang ditemukan hidup berkelompok dalam kawasan hutan dengan radius yang sangat sempit. Lokasi penelitian ada pada kisaran $250 \mathrm{~m}$ sampai $850 \mathrm{~m}$ dpl, dengan kondisi topografi relatif datar hingga bergelombang ringan. Kondisi ini secara umum memungkinkan adanya pohon penghasil gaharu tersebut dapat tumbuh, sesuai dengan yang dikatakan oleh Whit-

Tabel (Table ) 1. Jumlah pohon Aquilaria malaccensis pada setiap plot penelitian di Labanan Kabupaten Berau,

\begin{tabular}{|c|c|c|c|c|c|}
\hline \multirow{2}{*}{ Plot (Plots) } & \multicolumn{4}{|c|}{ Kelas diameter (Diameter class) ( cm) } & \multirow{2}{*}{ Jumlah (Sum, } \\
\hline & $10-19,9$ & $20-29,9$ & $30-39,9$ & $>40$ & \\
\hline 1 & 1 & 1 & - & - & 2 \\
\hline 2 & 1 & 1 & - & - & 2 \\
\hline 3 & 1 & - & - & - & 1 \\
\hline 4 & - & - & - & - & - \\
\hline 5 & 1 & 1 & 1 & - & 3 \\
\hline 6 & 2 & - & - & - & 2 \\
\hline 7 & 4 & - & - & - & 4 \\
\hline 8 & 1 & - & - & 1 & 2 \\
\hline 9 & 2 & - & - & - & 2 \\
\hline 10 & 2 & - & - & - & 2 \\
\hline 11 & 3 & 2 & - & - & 5 \\
\hline 12 & 3 & 1 & - & - & 4 \\
\hline
\end{tabular}
Kalimantan Timur (Number of Aquilaria malaccensis trees in each research plot, at Labanan Berau District, East Kalimantan) 


\begin{tabular}{|c|c|}
\hline Jumlah (Sum) & 29 \\
\hline Rata-rata (Average) & 0,02 \\
\hline $\begin{array}{l}\text { more (1972) bahwa habitat pohon peng- } \\
\text { hasil gaharu terutama terdapat di tempat } \\
\text { yang datar, di tepi atau di lereng pung- } \\
\text { gung bukit sampai pada ketinggian } 750 \mathrm{~m} \\
\text { dpl, dengan drainase yang baik. }\end{array}$ & $\begin{array}{l}\text { Bentuk ini juga merupakan bentuk umum } \\
\text { dari tegakan jenis di hutan alam. } \\
\text { Selanjutnya Smith (1962) menyata- } \\
\text { kan bahwa struktur suatu tegakan hutan } \\
\text { sangat dipengaruhi oleh faktor-faktor }\end{array}$ \\
\hline $\begin{array}{l}\text { Tingkat kehadiran jenis ini pada loka- } \\
\text { si penelitian sangat sedikit dengan kisar- } \\
\text { an satu sampai lima pohon setiap plot- } \\
\text { nya. Jika dihitung secara keseluruhan, } \\
\text { maka hanya didapat } 0,61 \text { pohon/ha. Data } \\
\text { ini cukup besar apabila dibandingkan de- } \\
\text { ngan hasil perolehan Rayan et al. (1997) } \\
\text { di Stasiun Penelitian Mentoko Taman } \\
\text { Nasional Kutai, dengan luasan } 300 \text { ha di- } \\
\text { temukan delapan pohon penghasil gaharu } \\
(0,027 \text { pohon/ha) dan pada demplot Wa- }\end{array}$ & $\begin{array}{l}\text { yang berpengaruh terhadap pertumbuhan } \\
\text { pohon penyusunnya, misalnya faktor bio- } \\
\text { tik dan genetik yang dimiliki setiap spe- } \\
\text { sies pohon serta faktor lingkungannya. } \\
\text { Jumlah pohon pada setiap kelas diameter } \\
\text { selalu berubah menurut waktu. Perubahan } \\
\text { tersebut disebabkan oleh adanya kecepat- } \\
\text { an pertumbuhan diameter pohon dalam } \\
\text { kelas diameter dan adanya variasi ruang } \\
\text { tumbuh yang diperlukan dalam partum- } \\
\text { buhan pohon. }\end{array}$ \\
\hline
\end{tabular}
nariset Samboja dengan luasan 265 ha ditemukan 21 pohon penghasil gaharu (0,079 pohon/ha).

Berdasarkan kelas diameter yang ada, jumlah pohon terbanyak berada pada kelas diameter kecil dan semakin besar diameter, jumlah pohon semakin sedikit. Seperti terlihat pada Gambar 2, sekitar 72\% pohon ada pada kelas diameter $10 \mathrm{~cm}$ dan $20 \%$ pohon ada pada kelas diameter 20 $\mathrm{cm}$. Sedangkan pohon dengan kelas diameter di atasnya hanya 8\%.

Dari Gambar 2 terlihat bahwa struktur dari jenis ini memiliki bentuk J-terbalik.

\section{Basal Area}

Berdasarkan luas bidang dasar, sebaran pohonnya dapat dilihat pada Tabel 2.

Basal area merupakan salah satu faktor penting untuk mengetahui suatu bidang, di mana basal area merupakan bidang atau bagian melintang dari suatu pohon pada ketinggian $\pm 1,3 \mathrm{~m}$ di atas permukaan tanah (Departemen Kehutanan, 1989). Jika dalam satuan pohon basal area tegakan merupakan suatu jumlah luas penampang dari seluruh pohon tersebut, basal area ini memberikan gambaran pohon yang menutupi suatu areal.

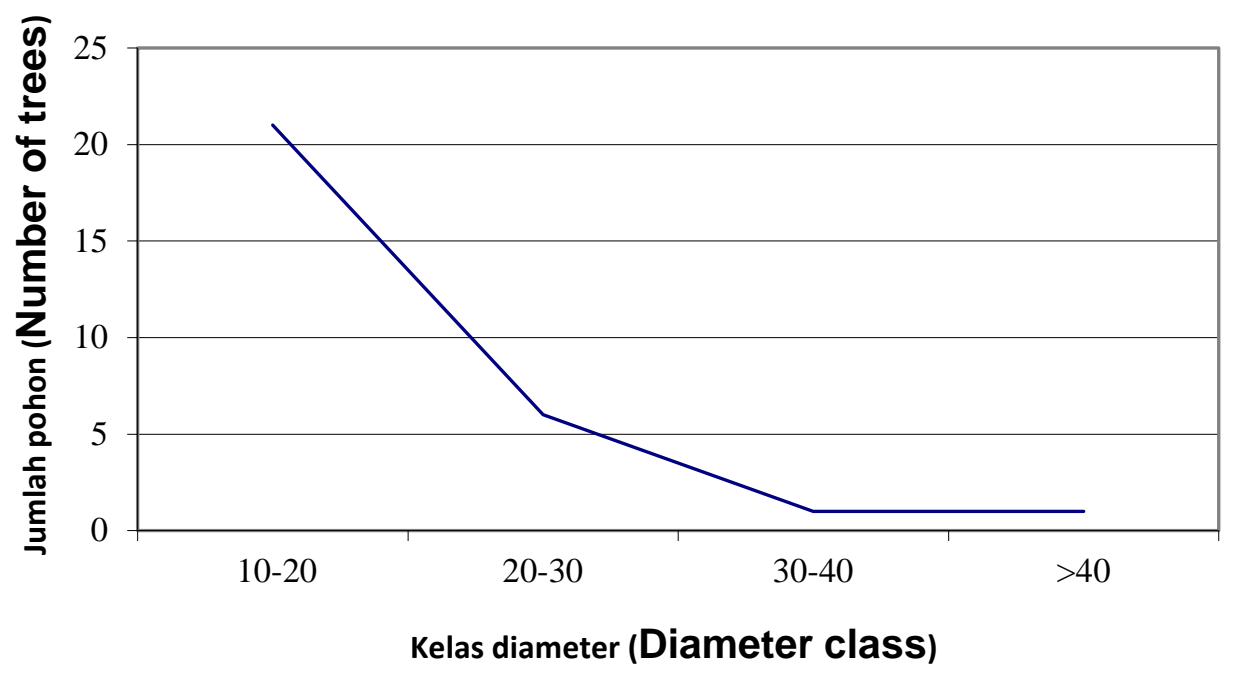

Gambar (Figure) 2. Jumlah pohon A. malaccensis berdasarkan kelas diameter yang terdapat pada plot penelitian di Labanan, Kabupaten Berau, Kalimantan Timur (Number of A. malaccensis 
trees according to diameter class at permanent sample plots at Labanan, Berau District, East Kalimantan)

Tabel (Table) 2. Luas bidang dasar A. malaccensis pada setiap plot penelitian di Labanan Kabupaten Berau, Kalimantan Timur (Basal area of A. malaccensis at research plots at Labanan Berau District, East Kalimantan)

\begin{tabular}{|c|c|c|c|c|c|}
\hline \multirow{3}{*}{ Plot (Plots) } & \multicolumn{5}{|c|}{ Bidang dasar (Basal area) $\left(\mathrm{m}^{2}\right)$} \\
\hline & \multicolumn{4}{|c|}{ Kelas diameter (Diameter class) $(\mathrm{cm})$} & \multirow{2}{*}{$\begin{array}{c}\text { Jumlah (Sum) } \\
\left(\mathrm{m}^{2}\right)\end{array}$} \\
\hline & $10-19,9$ & $20-29,9$ & $30-39,9$ & $>40$ & \\
\hline 1 & 0,016513 & 0,053502 & - & - & 0,070015 \\
\hline 2 & 0,022432 & 0,056832 & - & - & 0,079264 \\
\hline 3 & 0,02688 & - & - & - & 0,02688 \\
\hline 4 & - & - & - & - & - \\
\hline 5 & 0,14957 & 0,033979 & ,086049 & & 0,269598 \\
\hline 6 & 0,02880 & - & - & & 0,02880 \\
\hline 7 & 0,063275 & - & - & & 0,063275 \\
\hline 8 & 0,012469 & - & - & 0,15693 & 0,169399 \\
\hline 9 & 0,027128 & - & - & - & 0,027128 \\
\hline 10 & 0,031907 & - & - & - & 0,031907 \\
\hline 11 & 0,047141 & 0,090372 & - & - & 0,137513 \\
\hline 12 & 0,038681 & 0,039057 & - & - & 0,077738 \\
\hline Rata-rata (Average) (plot) & 0,042254 & 0,054748 & 0,086049 & 0,15693 & 0,089229 \\
\hline Rata-rata (Average) per ha & 0,010564 & 0,013687 & 0,021512 & 0,039233 & 0,022307 \\
\hline
\end{tabular}

Dari Tabel 2 dapat dilihat bahwa basal area terbesar terdapat pada kelas diameter kecil. Hal ini sesuai dengan jumlah pohon yang banyak ditemukan pada kelas tersebut. Tetapi jika dilihat dari perbandingan antara jumlah pohon dan basal area, maka akan terlihat perbedaan yang cukup mencolok yaitu persentase total basal area kelas $10 \mathrm{~cm}$ adalah $47 \%$ dengan persentase jumlah pohon $72 \%$, sedangkan persentase basal area kelas 20 $\mathrm{cm}$ mencapai $27 \%$ dengan persentase jumlah pohon $20 \%$.

Secara keseluruhan, rata-rata luas bidang dasar A. malaccensis hanya 0,022 $\mathrm{m}^{2} /$ ha, sedangkan rata-rata bidang dasar pada plot ini adalah $31,5 \mathrm{~m}^{2} / \mathrm{ha}$ (Sist dan Saridan, 1998). Ini juga memberikan indikasi bahwa potensi atau kehadiran jumlah jenis pada lokasi ini sangat rendah.

Jumlah basal area terbesar terdapat pada plot 5 disusul plot 8 dan 11 . Hal ini akan terlihat berbeda dengan jumlah pohon di mana jumlah pohon terbesar berada pada plot 11 disusul plot 7 dan 12 dengan jumlah yang sama. Hal ini juga menggambarkan bahwa pada plot terse- but memiliki pohon dengan diameter yang besar, walaupun jumlah pohon lebih sedikit.

\section{B. Riap}

\section{Riap Diameter}

Riap adalah penambahan diameter, luas pangkal, tinggi, volume, kualitas, atau nilai pohon-pohon atau tegakan dikaitkan dengan waktu (Departemen Kehutanan, 1989). Sehubungan dengan hal tersebut maka riap diameter merupakan salah satu informasi untuk mengetahui besarnya nilai penambahan tersebut. Untuk menaksir kisaran peubah riap diameter, digunakan nilai-nilai statistik dari sejumlah contoh pengukuran.

Jenis pohon ini sangatlah sulit/langka didapat di lapangan sehingga pengukuran riap ini berdasarkan pohon yang ada pada plot, walaupun demikian diharapkan hasil ini memberikan tambahan informasi yang diharapkan dari pertumbuhan itu sendiri.

Dari dua kali pengukuran diameter (2001 dan 2003) terhadap 49 individu pohon diperoleh riap diameter yang merupakan selisih pengukuran diameter terse- 
but. Nilai statistik yang dihitung adalah rata-rata, simpangan baku, ragam dan galat baku untuk menggambarkan keadaan nilai peubah riap diameter yang diukur.

Dari hasil perhitungan tersebut didapat nilai rata-rata riap diameter adalah $0,40 \mathrm{~cm} /$ th dengan galat baku (Se) = $0,0402 \mathrm{~cm}$ (Tabel 3). Kisaran nilai riap diameter populasi $(\mu)$ yang dapat memenuhi tingkat keyakinan (confidence) atau kemungkinan (probabilitas) 95\% adalah antara 0,318333-0,480239 $\mathrm{cm} /$ th. Nilai ini diperoleh berdasarkan rumus $\mu=\mathrm{x} \pm$ $\mathrm{t}^{*}$ Se, dalam hal ini $\mathrm{t}=2,0092$. Angka yang termasuk dalam kisaran nilai riap diameter ini cukup kecil bila dibandingkan dengan asumsi umum yang mengatakan bahwa riap rata-rata diameter pohonpohon tegakan hutan alam di Indonesia sekitar $1 \mathrm{~cm} /$ tahun (Anonim, 1976).

Nilai riap pohon pada hutan alam ini kecil jika dibandingkan dengan hasil penanaman yang dilakukan oleh Balai Penelitian dan Pengembangan Kehutanan Kalimantan (BP2KK) di arboretum sebagaimana yang dilaporkan Ngatiman dan Siran (2003). Pada laporan tersebut disebutkan bahwa $A$. malaccensis yang berumur sembilan tahun dengan jarak tanam 5 $\mathrm{m}$ x $5 \mathrm{~m}$ dapat mencapai diameter antara 14,7-20,1 cm. Tanaman ini berarti memiliki rata-rata pertumbuhan antara 1,672,23 cm per tahun. Hal ini menunjukkan pertumbuhan yang cukup besar jika dilihat dari pertumbuhan hutan alam yang hanya memiliki pertumbuhan sebesar satu cm/tahun (Anonim, 1976). Lebih jauh Rayan (2000) melaporkan bahwa dari hasil uji coba perlakuan jarak tanam yang dicobakan yaitu $1,0 \mathrm{~m} ; 1,5 \mathrm{~m}$; dan 2,0 m, hasilnya menunjukkan bahwa jarak tanam yang lebih besar yaitu jarak tanam 2,0 m memberikan hasil pertumbuhan yang terbaik. Hal ini mengindikasikan bahwa ruang tumbuh dan cahaya sangat diperlukan oleh jenis ini. Sebaliknya A.malaccensis yang ada di hutan alam tidak memperoleh cahaya dan ruang tumbuh yang cukup sehingga keberadaan pohon yang ada di bawah tajuk pohon besar akan menjadi tertekan yang mengakibatkan riap diamater menjadi kecil.

\section{Pergeseran Sebaran Diameter}

Untuk melihat pergeseran diameter ini, semua hasil pengukuran, baik yang pertama (tahun 2001) dan kedua (tahun 2003), dikelompokkan ke dalam kelas diameter di mana kelas yang terkecil adalah $10 \mathrm{~cm}$ dan tertinggi $40 \mathrm{~cm}$ dengan selang antar kelas sebesar $10 \mathrm{~cm}$ seperti tertera pada Gambar 3.

Dari Gambar 3 terlihat bahwa sebaran diameter masih menyebar pada kelas kecil. Selanjutnya bila dari kedua pengukuran ini digabungkan, maka dapat dilihat terjadi pergeseran frekuensi jumlah pohon. Hal ini disebabkan adanya pertumbuhan dari pohon itu sendiri yang mengakibatkan pohon masuk pada kelas diameter di atasnya atau yang meninggalkan kelas-kelas diameter semula karena diameter yang semakin besar.

Batas terendah kedua sebaran kelas diameter, baik pengukuran pertama maupun pada pengukuran kedua masih tetap yaitu $10 \mathrm{~cm}$, tetapi jumlahnya berkurang. Beberapa pohon pada kelas tersebut diameternya bertambah besar yang mengakibatkan jumlah pada kelas diameter di atasnya naik, walaupun pada kelas di atasnya juga ada yang naik pada kelas berikutnya. Pergeseran ini nampak jelas pada kelas $20 \mathrm{~cm}$ di mana terjadi penambahan yang cukup besar. Pergeseran ini merupakan hal yang wajar sebagai gejala umum dalam sebaran diameter untuk membandingkan hasil dari suatu pengukuran.

Tabel (Table) 3. Nilai rata-rata riap diameter, simpangan baku, galat baku dan ragam A. malaccensis di plot penelitian Labanan Berau, Kalimantan Timur (Value of average, standard deviation, standard error and variance A. malaccensis diameter at permanent sample plots at Labanan, Berau District, East Kalimantan) 


\begin{tabular}{ccccc}
\hline Item & $\begin{array}{c}\text { Rata-rata } \\
\text { (Average) }(\mathrm{cm} / \text { th) }\end{array}$ & $\begin{array}{c}\text { Simpangan baku } \\
\text { (Standard deviation) }\end{array}$ & $\begin{array}{c}\text { Ragam } \\
\text { (Variance) }\end{array}$ & $\begin{array}{c}\text { Galat baku } \\
\text { (Standard error })\end{array}$ \\
\hline Riap diameter (Increment) & 0,397389 & 0,282198 & 0,079635 & 0,040291 \\
\hline
\end{tabular}

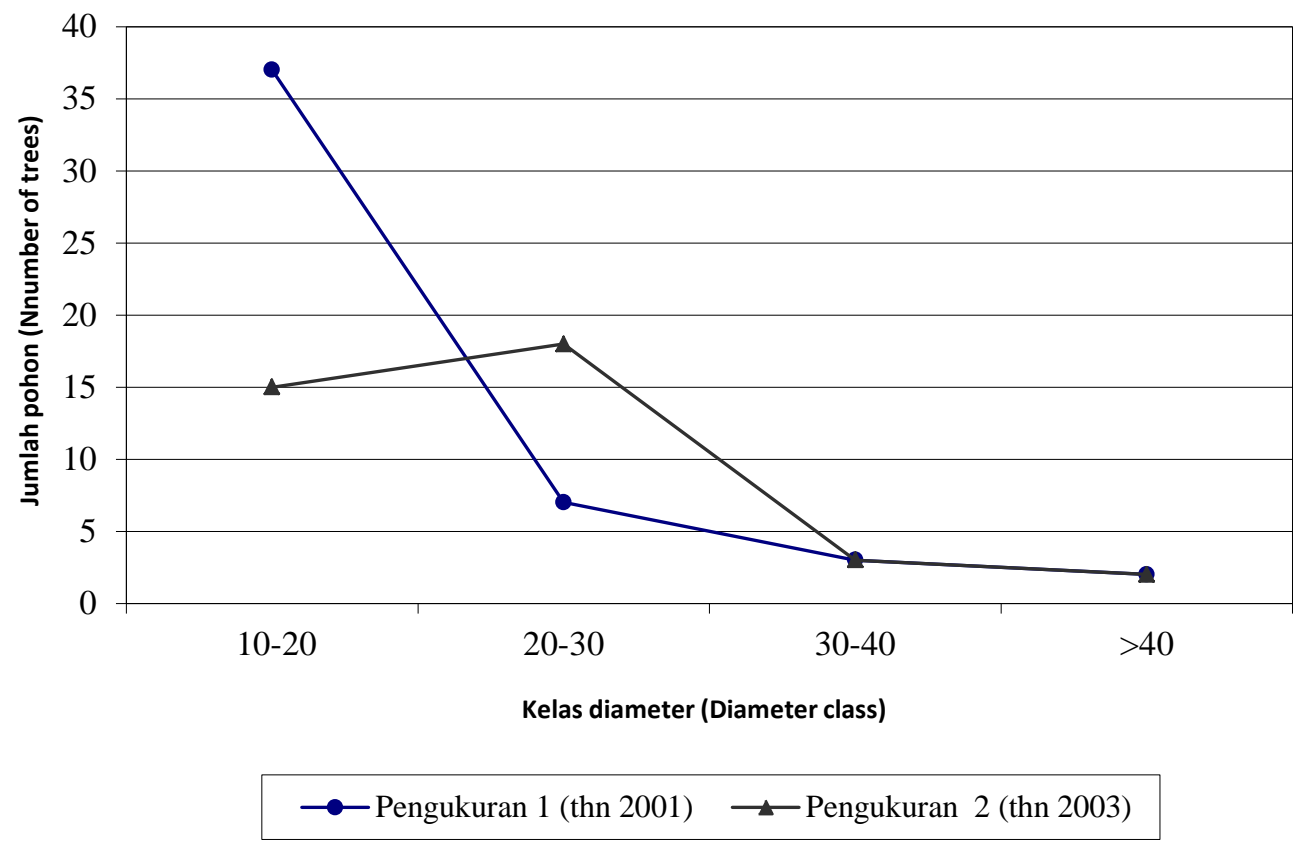

Gambar (Figure) 3. Pergeseran sebaran kelas diameter A. malaccensis yang terdapat dalam plot penelitian di Labanan Kabupaten Berau, Kalimantan Timur (Shifting of diamater class distribution A. malaccensis area at permanent sample plots at Labanan Berau District, East Kalimantan)

Jika dilihat kurva kumulatifnya, pergeseran hasil pengukuran juga terjadi. Jumlah pohon pada pengukuran pertama ada di atas jumlah pohon pada pengukuran kedua. Hal ini menunjukkan bahwa ada selisih antara hasil pengukuran satu dan dua. Perbedaan ini tidak terlalu besar jika dilihat selisih dari kedua garis tersebut yang cukup rapat. Secara kumulatif pertambahan diameter per tahun dapat dilihat pada Gambar 4.

\section{Pertumbuhan Berdasarkan Kelas Diameter}

Hasil perhitungan data yang diperoleh di lapangan untuk mengetahui partumbuhan masing-masing kelas diameter dapat dilihat pada Gambar 5.

Dari Gambar 5 terlihat bahwa pertumbuhan terbesar ada pada kelas $30 \mathrm{~cm}$ yaitu sebesar 0,63 cm/tahun dan $40 \mathrm{~cm}$ sebesar 0,64 cm/tahun. Data yang ada ha- nya sampai kelas tersebut sehingga gambaran mengenai kelas diameter di atasnya tidak dapat dilihat. Hal ini juga sesuai dengan yang dilaporkan oleh Heyne (1987) bahwa A. malaccensis dapat mencapai diameter $50 \mathrm{~cm}$.

Hal di atas mengindikasikan bahwa persaingan untuk memperoleh ruang dan cahaya yang cukup sangat berpengaruh terhadap kecepatan pertumbuhan. Pada kelas tersebut pohon lebih mendapatkan cahaya yang cukup bila dibandingkan dengan kelas di bawahnya yang tertutup oleh tajuk. Sebagaimana telah dijelaskan dari penelitian yang dilakukan oleh Rayan (2000); Ngatiman dan Siran (2003) bahwa karakteristik dari jenis A. malaccensis memerlukan cahaya yang cukup.

Abdurachman et al. (1995), Ong dan Klein (1996), dan Abdurachman (1999) menyatakan bahwa pertumbuhan terbesar pada jenis pohon meranti di hutan alam ada pada kelas $30-50 \mathrm{~cm}$, hal ini terjadi 
juga pada jenis $A$. malaccensis di mana pertumbuhan terbesar ada pada kelas ter- sebut.

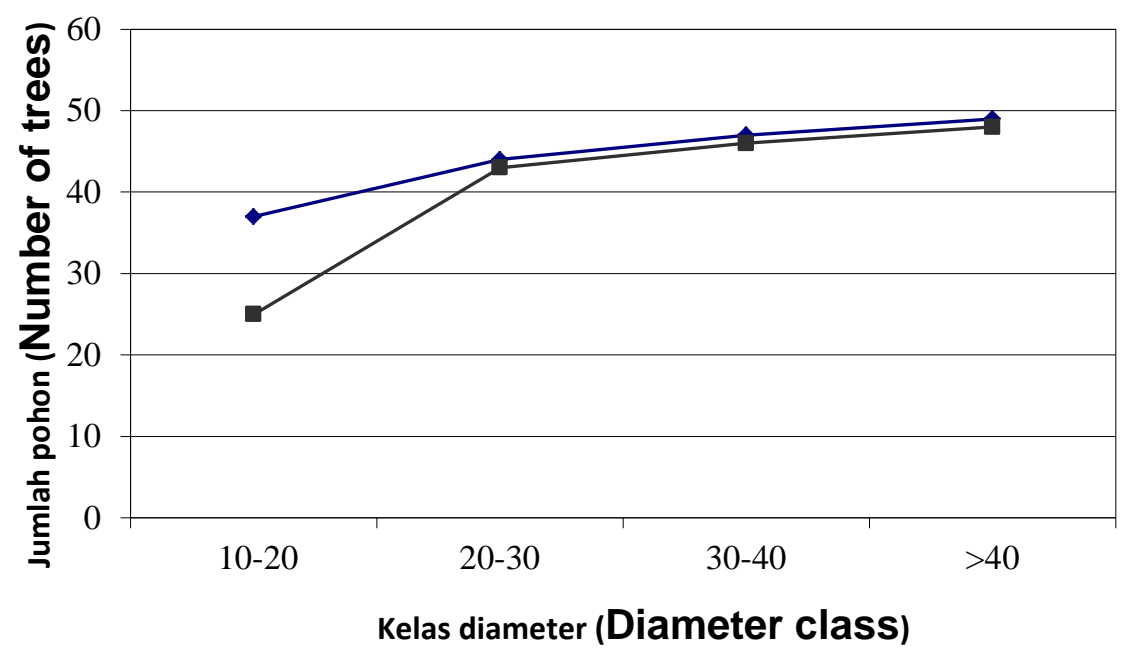

$\longrightarrow$ Pengukuran $1 \rightarrow$ Pengukuran 2

Gambar (Figure) 4. Kurva kumulatif frekuensi relatif A. malaccensis yang terdapat dalam plot penelitian di Labanan Kabupaten Berau, Kalimantan Timur (Curve of relative frequency cumulative of A. malaccensis at permanent sample plots at Labanan Berau District, East Kalimantan)

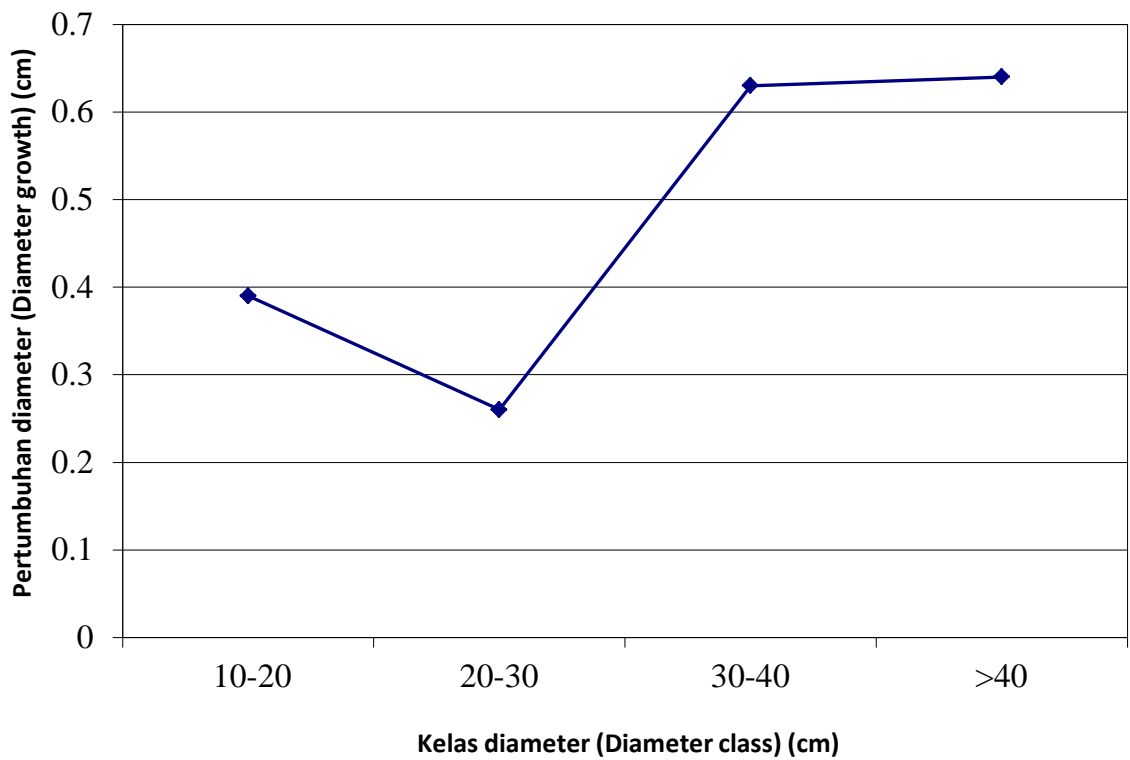

Gambar (Figure) 5. Grafik pertumbuhan diameter berdasarkan kelas diameter A. malaccensis yang terdapat dalam plot penelitian di Labanan Kabupaten Berau, Kalimantan Timur (Graphic of diameter growth for each diameter class of A. malaccensis area at permanent sample plots at Labanan Berau District, East Kalimantan)

\section{IV.KESIMPULAN DAN SARAN}

\section{A. Kesimpulan}

1. Pohon penghasil gaharu (Aquilaria malaccensis LAMK) yang ditemui di dalam plot penelitian STREK Labanan, Berau Kalimantan Timur seluas 
48 ha berjumlah 29 pohon dan ratarata terdapat satu pohon pada luasan kawasan hutan dua ha atau 0,5 batang/ha. Jenis ini umumnya tumbuh pada topografi yang relatif datar.

2. Dominasi kelas diameter pada urutan teratas pada kelas $10-20 \mathrm{~cm}(72,4 \%)$ disusul kelas 20-30 cm (20,7\%) dan kelas di atasnya 6,9\%; sedangkan basal area hanya $0,020657 \mathrm{~m}^{2} / \mathrm{h}$. Dengan kata lain nilai ini sangat rendah.

3. Frekuensi jumlah pohon antar kelas mengalami pergeseran kelas diameter yang mengindikasikan adanya pertambahan diameter. Walaupun pada pengukuran satu batas terendah kelas diameter masih tetap, tetapi jumlahnya sudah berkurang atau terjadi penurunan frekuensi.

4. Riap rata-rata diameter Aquilaria malaccensis LAMK per tahun adalah $0,40 \mathrm{~cm}$ dengan galat baku $0,04 \mathrm{~cm}$.

5. Pertumbuhan maksimum terjadi pada kelas interval $>40 \mathrm{~cm}$ yaitu sebesar $0,64 \mathrm{~cm} /$ tahun.

\section{B. Saran}

1. Potensi pohon penghasil gaharu yang rendah tidak sebanding dengan perburuan gaharu yang terus berlangsung. Untuk itu usaha konservasi dan penanaman perlu dilakukan. Usaha penyebarluasan tentang teknik-teknik pemilihan pohon yang berisi gaharu perlu dilakukan agar para pemburu gaharu tidak asal menebang pohon (termasuk yang tidak berisi gaharu).

2. Perlu dikaji peraturan tentang kewajiban bagi para pemegang hak pengusahaan hutan untuk melakukan pengayaan jenis pohon penghasil gaharu pada tanah yang kosong atau pada kawasan hutan yang kurang terdapat jenis komersil dengan proporsi yang disesuaikan kondisi topografi. Peraturan tersebut dapat digabungkan atau dituangkan dalam peraturan TPTI
(Tebang Pilih Tanam Indonesia) maupun keputusan lainnya.

3. Perlu dilakukan pengamatan partumbuhan yang sejenis untuk tempat lain dan juga sampel pohon yang lebih besar sehingga didapat informasi yang lebih lengkap tentang perkembangan tegakan dan selanjutnya informasi ini dapat dijadikan dasar di dalam mengelola jenis ini.

\section{DAFTAR PUSTAKA}

Abdurachman, A. Saridan dan P. Subagio. 1995. Pertumbuhan Diameter Jenis-jenis Shorea di Hutan Alam PT. Inhutani I Berau, Kalimantan Timur. Wanatrop 8(2). Samarinda.

Abdurachman. 1999. Pertumbuhan Diameter Jenis-jenis Shorea di Hutan Bekas Tebangan PT. Sari Bumi Kusuma, Kalimantan Tengah. Wanatrop 13(2). Samarinda.

Anonim. 1976. Vademicum Kehutanan Indonesia. Departemen Pertanian, Direktorat Jenderal Kehutanan. Jakarta.

Anonim. 1999. PT. Inhutani Labanan Menuju Pengelolaan Hutan Lestari. (Tidak Diterbitkan).

Departemen Kehutanan. 1989. Kamus Kehutanan Edisi Pertama. Departemen Kehutanan Republik Indonesia. Jakarta.

Heyne, K. 1987. Tumbuhan Berguna Indonesia. Badan Penelitian dan Pengembangan Kehutanan, Departemen Kehutanan. Jakarta.

Junus, M., A.R. Wasarakaet, J.J. Fransz, M. Rusmaedi, S. Soedirman, S.N. Digut dan M. Sila. 1985. Dasar Umum Ilmu Kehutanan. Buku II. Kegiatan dalam Bidang Kehutanan. Badan Kerjasama Perguruan Tinggi Negeri Indonesia Bagian Timur. Ujung Pandang.

Ngatiman dan S.A. Siran. 2003. Informasi Awal Pembentukan Gaharu pada 
Pohon Penghasil Gaharu (Aquilaria malaccensis LAMK). Prosiding Promosi Investasi dan Pelatihan Teknologi Perakaran Tanaman (Mikoriza) di Propinsi Kalimantan Timur. Samarinda.

Ong, R.C. and M. Kleine. 1996. Dipsim: Dipterocarp Forest Growth Simulation Model, A Tool for Forest Level Management Planning. Dipterocarp Forest Ecosystem Towards Sustainable Management. Singapore.

Rayan, A. Saridan dan Yusliansyah. 1997. Sebaran Pohon Gaharu (Aquilaria malaccensis LAMK) di Daerah Mentoko dan Wanariset Samboja, Kalimantan Timur. Buletin Penelitian Kehutanan 12(1). BPK Samarinda.

Rayan. 2000. Perlakuan Lebar Jalur Tanam terhadap Pertumbuhan Tanaman Gaharu (Aquilaria malaccensis LAMK). Dipterokarpa 5(1). Samarinda.

Saridan, A. 1984. Analisis Vegetasi Hutan Riparian Sepanjang Sungai Mahakam Bagian Hilir (Muara Kembang sampai Pulau Tenggarong).
Skripsi Sarjana Kehutanan Universitas Mulawarman Samarinda. (Tidak Diterbitkan).

Schmidt, F. H. and J. H. A. Ferguson. 1951. Rainfall Type Based on Wet and Dry Period Ratios for Indonesia with Western New Guinea. Verhand 42. Direktorat Meteorologi dan Geofisika. Jakarta.

Sist, P. and A. Saridan. 1998. Description of the Primary Low Land Forest of Berau. Silvicultural Research in a Low Land Mixed Dipterocarp Forest of East Kalimantan. Cirad Foret France.

Smith, D.M. 1962. The Practice of Silviculture. Seventh Edition. John Willey and sons Inc. New York.

Snedecor, G. W. and W.H. Cochran. 1956. Statistical Methods. Sixth Edition. The Iowa University Press, Ames. Iowa.

Whitmore, T. C. 1972. Tree Flora of Malaysia. A Manual for Foresters Vol. II. Forestry Research Institute of Malaysia. Kepong. 